\title{
The effect of mouse strain on herpes simplex virus type 1 (HSV-1) infection of the central nervous system (CNS)
}

Lorne F Kastrukoff ${ }^{1 *+}$, Allen S Lau ${ }^{1+}$ and Eva E Thomas ${ }^{2+}$

\begin{abstract}
Background: Mice infected with HSV-1 can develop lethal encephalitis or virus induced CNS demyelination. Multiple factors affect outcome including route of infection, virus and mouse strain. When infected with a sublethal dose of HSV-1 strain 2 via the oral mucosa, susceptible SJL/J, A/J, and PL/J mice develop demyelinating lesions throughout the brain. In contrast, lesions are restricted to the brainstem (BST) in moderately resistant BALB/ c mice and are absent in resistant BL/6 mice. The reasons for the strain differences are unknown.

Methods: In this study, we combine histology, immunohistochemistry, and in-situ hybridization to investigate the relationship between virus and the development of lesions during the early stage ( $<24$ days $\mathrm{Pl}$ ) of demyelination in different strains of mice.

Results: Initially, viral DNA and antigen positive cells appear sequentially in non-contiguous areas throughout the brains of BALB/C, SJL/J, A/J, and PL/J mice but are restricted to an area of the BST of BL/6 mice. In SJL/J, A/J, and $\mathrm{PL} / \mathrm{J}$ mice, this is followed by the development of 'focal' areas of virus infected neuronal and non-neuronal cells throughout the brain. The 'focal' areas follow a hierarchical order and co-localize with developing demyelinating lesions. When antigen is cleared, viral DNA positive cells can remain in areas of demyelination; consistent with a latent infection. In contrast, 'focal' areas are restricted to the BST of BALB/C mice and do not occur in BL/6 mice.

Conclusions: The results of this study indicate that susceptible mouse strains, infected with HSV-1 via the oral mucosa, develop CNS demyelination during the first 24 days PI in several stages. These include: the initial spread of virus and infection of cells in non-contiguous areas throughout the brain, the development of 'focal' areas of virus infected neuronal and non-neuronal cells, the co-localization of 'focal' areas with developing demyelinating lesions, and latent infection in a number of the lesions. In contrast, the limited demyelination that develops in BALB/C and the lack of demyelination in BL/6 mice correlates with the limited or lack of 'focal' areas of virus infected neuronal and non-neuronal cells in these two strains.
\end{abstract}

Keywords: Herpes simplex virus 1(HSV-1), Central nervous system (CNS) infection, Mouse strain, dependent effect, HSV-1 induced CNS demyelination

\section{Background}

HSV-1 is a common infection in developed countries where rates of seropositivity usually exceed $50 \%[1,2]$. In both humans and experimental animals, primary infection of the skin or mucosa results in the local replication

\footnotetext{
* Correspondence: lornefk@interchange.ubc.ca

+ Contributed equally

'Department of Medicine, University of British Columbia, Vancouver V6T 1Z3, Canada
}

Full list of author information is available at the end of the article of virus, infection of sensory nerve endings, and spread via retrograde axonal transport to the ganglia of the peripheral nervous system (PNS) where a productive infection of neurons ensues $[1,2]$. Although infectious virus is eventually cleared, a latent infection is established in neurons of the PNS ganglia $[3,4]$.

HSV-1infection of the CNS is more complex with virus transmitted across synapses during primary infection and the development of latent infection in the brains of both humans [5-7] and experimental animals

\section{Ciomed Central}


[8-10]. In humans, HSV-1 is a common cause of sporadic viral encephalitis $[11,12]$ with mortality rates reaching 20-30\% despite treatment [13]. Mice infected with HSV-1 can also develop lethal encephalitis with resistance to mortality being mouse strain dependent $[14,15]$. Further, HSV-1 is implicated in the development of CNS demyelinating disease in humans but its' role remains controversial [16-20]. Although a high incidence of HSV-1 in the brains and active plaques of MS patients is reported $[21,22]$, virus is also present in controls. Recent studies, however, report an increased risk of MS in HSV-1 infected individuals without the DRB1*15 allele [23]; raising the possibility that this virus may play a role in the development of MS in individuals with a specific genotype. HSV-1 can also induce CNS demyelination in mice with the nature of the demyelinating lesions reported to be dependent on virus strain [24-31], route of infection [32], and mouse strain $[33,34]$. The mechanisms mediating the mouse strain effect are largely unknown. In this study, we combine histology, immunohistochemistry, and in-situ hybridization to investigate the relationship between virus and the development of lesions during the early stage $(<24$ days PI) of demyelination in different strains of mice.

\section{Methods}

Mice

Inbred 8-10 week $9 \mathrm{BL} / 6, \mathrm{BALB} / \mathrm{c}, \mathrm{SJL} / \mathrm{J}, \mathrm{A} / \mathrm{J}$, and PL/J mice were purchased from the Jackson Laboratory, Bar Harbor, ME. Mice were housed in animal facilities of the Faculty of Medicine, University of British Columbia (UBC), and infected at 10 to 12 weeks of age. Principles of animal care (NIH publication No. 86-23, revised 1985) were followed in these studies along with the guidelines of the Institutional Animal Care and Use Committee of UBC.

\section{Virus and cells}

HSV-1 (strain 2) was grown on BHK-21 cells with viral titers determined by plaque assay [35]. This strain of HSV-1 was isolated from human trigeminal ganglia, plaque purified, and characterized by Dr. Moira Brown (MRC Institute for Virology, Glasgow) [35,36]. The strain was selected from a large number of laboratory and clinical isolates because of the ability to induce CNS demyelination. Virus was stored at $-80^{\circ} \mathrm{C}$ until used. The oral mucosa was inoculated with a sub-lethal dose, $2 \times 10^{5}$ plaque forming units (PFU) of virus, or mock infected using a scarification method previously described [33].

\section{Histology}

The brains of three mice of each strain were removed at necropsy every 3 days PI and up to 30 days post-infection (PI). Additional mice were examined on intervening days as necessary.
Mice were perfused in-vivo with $4 \%$ paraformaldehyde in phosphate buffered saline (PBS). CNS tissue was dehydrated in alcohol and toluol, embedded in paraffin, and serially sectioned. Six micron thick coronal sections of the cerebral hemispheres (CR) along with transverse sections of the BST and cerebellum (CB) were made. Sections were counter stained with either hematoxylin-eosin ( $H$ \& E), cresyl fast violet (CFV), or Luxol fast blue-cresyl fast violet (LFB-CFV). Sections were coded and examined in a blinded fashion with an Olympus BHS microscope.

\section{Immunohistochemistry (IHC)}

Serial sections of the CR and BST-CB were examined by PAP IHC. Detection of HSV viral antigens employed polyclonal rabbit anti-HSV-1 antisera (B0114) that recognizes all viral proteins (DAKO, Burlingham, ON). Sections were pretreated with $0.5 \%$ hydrogen peroxide and washed in $0.05 \mathrm{M}$ Tris-saline (pH7.6) plus 1\% normal goat serum prior to incubation with anti-sera. This was followed by treatment with goat anti-rabbit IgG, rabbit PAP, and 0.03\% 3-3' diaminobenzydine. Sections were counterstained with either CFV or LFB-CFV.

\section{In-situ hybridization (ISH)}

Serial sections of the CR and BST-CB were examined by ISH. Sections were mounted on glass slides, deparaffinated, and rehydrated. Tissue was treated with $0.02 \mathrm{M}$ HCL, washed, and treated with $0.01 \%$ Triton X-100 in PBS. Washed sections were treated with pronase $(2.0 \mathrm{mg} /$ $\mathrm{ml}$ in $50 \mathrm{mM}$ Tris- $\mathrm{HCl}, \mathrm{pH} 7.4$ ), postfixed in $4 \%$ paraformaldehyde in PBS, treated with $100 \mathrm{mM}$ triethanlamine ( $\mathrm{pH}$ 8.0) plus $25 \mathrm{mM}$ acetic anhydride and dehydrated in ethanol. Sections were then treated with a prehybridization mixture (2x SSC, formamide, Denhardt's solution, salmon sperm DNA, dextran sulfate) for $20 \mathrm{~min}$ at room temperature (RT). This was followed by treatment with a hybridization mixture (2x SSC, dextran sulfate, formamide, salmon sperm DNA, DTT, Denhardt's solution, ${ }^{35} \mathrm{~S}$ labelled HSV cDNA) at $90^{\circ} \mathrm{C}$ for 7 min followed by $37^{\circ} \mathrm{C}$ for $16-24 \mathrm{hrs}$. The HSV cDNA probe was a $15 \mathrm{~kb}$ fragment (fragment $G$ ) derived from HSV-1 strain F and cloned in pTZ18. Specific activity of the probe was $2-7 \times$ $10^{8} \mathrm{cpm} / \mu \mathrm{g}$ of DNA. The fragment was previously determined not to cross react with cellular DNA. The tissue was washed, dehydrated in ethanol with $0.3 \mathrm{M}$ ammonium acetate, air dried and coated with NTB-2 emulsion. The slides were stored at $4^{\circ} \mathrm{C}$ for two weeks, developed, and counterstained with $\mathrm{H} \& \mathrm{E}$.

\section{Statistics}

All analyses for statistically significant differences were performed with Student's $t$ test. $P<0.05$ is considered significant. 


\section{Results}

Three HSV-1 infected mice of each strain (BL/6, BALB/ c, SJL/J, A/J, and PL/J) were examined at necropsy every 3 days from day 0 through 30 PI. In some cases, additional mice were examined on intervening days along with mock infected controls. CR and BST-CB were serially sectioned and yielded $\sim 300$ sections of the CR and $\sim 140$ sections of the BST-CB per mouse. The serial sections were examined for viral DNA by ISH with $\mathrm{H} \& \mathrm{E}$ counterstain, for viral antigen by IHC and CFV counterstain, or both viral antigen and demyelination by IHC with LFB-CFV counterstain. None of the mock infected controls were positive for HSV-1 DNA, viral antigen, or CNS demyelination.

\section{In BL/6 mice, HSV-1 DNA and antigen positive cells are restricted to the $\mathrm{BST}$}

In $\mathrm{BL} / 6$ mice infected with $\mathrm{HSV}-1$ strain 2 via the oral mucosa, the spread of infectious virus is restricted to the BST [37] and CNS demyelinating lesions do not occur [33]. To further examine the location of viral DNA and antigen in the brain, HSV-1 infected 10-12 week $q$ BL/6 mice were examined every 3 days from day 0 through 30 PI. Viral DNA and antigen positive cells cannot be identified throughout the brain nor are they present diffusely throughout the BST (data not shown). Viral DNA (Figure 1a-c) and antigen (Figure $1 d-f)$ positive cells are restricted to a small area of the $\mathrm{BST}$ in relation to the roots of the trigeminal nerve (RTNBST). The appearance and clearance of viral antigen in the brains of $\mathrm{BL} / 6$ mice is 3 and 12 days PI respectively (Table 1 ) but viral DNA positive cells can remain for at least 30 days PI (data not shown).

\section{In BALB/c mice, HSV-1 antigen positive cells appear sequentially in non-contiguous areas throughout the brain}

In $\mathrm{BALB} / \mathrm{c}$ mice, infected with $\mathrm{HSV}-1$ strain 2 via the oral mucosa, virus spreads throughout the brain [37] but CNS demyelinating lesions are restricted to the trigeminal root entry zone of the BST [33]. To identify viral antigen in the brain, HSV-1 infected 10-12 week o $\mathrm{BALB} / \mathrm{c}$ mice were examined every 3 days from day 0 through $30 \mathrm{PI}$. In contrast to $\mathrm{BL} / 6$ mice, viral antigen positive cells in BALB/c mice appear sequentially in non-contiguous areas throughout the brain. Antigen positive cells first appear in the BST on day 3 PI (Figure $2 \mathrm{a} \& 2 \mathrm{~b}$ ), in the CB on day 6 PI (Figure $2 \mathrm{~d} \& 2 \mathrm{e}$ ), and in the CR on day 7 PI (Figure 2g). Many of the cells have the morphology of neurons (Figure 2c, 2f, \& 2h). Viral antigen positive cells also appear sequentially in non-contiguous areas throughout the brains of SJL/J, $\mathrm{A} / \mathrm{J}$, and $\mathrm{PL} / \mathrm{J}$ mice (data not shown). In BALB/c mice, 'focal' areas of viral antigen positive neuronal and nonneuronal cells are restricted to an area in relation to the RTNBST (data not shown). The appearance and clearance of viral antigen in the brains of BALB/c mice is 3 and 18 days PI respectively (Table 1 ) but viral DNA positive cells can remain for at least 30 days PI (data not shown).

\section{In SJL/J, A/J, and PL/J mice, 'focal' areas of viral antigen positive neuronal and non-neuronal cells appear sequentially in non-contiguous areas throughout the brain} In SJL/J, A/J, and PL/J mice, infected with HSV-1 strain 2 via the oral mucosa, infectious virus spreads sequentially throughout the brain [33] and is associated with the development of early stage ( $<24$ days PI) CNS demyelination throughout the brain [34]. To identify 'focal' areas of viral DNA and antigen positive neuronal and non-neuronal cells throughout the brain, HSV-1 infected 10-12 week $q$ mice of all three strains were examined every three days from day 0 through 30 PI. In PL/J mice, 'focal' areas of HSV-1 DNA positive cells appear sequentially in non-contiguous areas throughout the brain. These areas are shown in representative sections of the BST (Figure 3a-c) and CB (Figure 3g-i). 'Focal' areas of viral antigen positive cells in $\mathrm{PL} / \mathrm{J}$ mice also appear sequentially in non-contiguous areas throughout the brain. These areas are shown in representative sections of BST (figure 3d-f) and CB (Figure $3 \mathrm{j}-1)$. 'Focal' areas of HSV-1 DNA positive and antigen positive cells also develop throughout the brains of SJL/J and A/J mice (data not shown). The appearance and clearance of the 'focal' areas are mouse strain dependent (Table 1).

\section{Number and size of the 'focal' areas of viral antigen positive cells define a hierarchy among different strains of mice}

The number and size of CNS demyelinating lesions define a hierarchical order among different strains of mice infected with HSV-1 strain 2 via the oral mucosa [34]. To identify the number and size of 'focal' areas of viral antigen positive cells in the brain, HSV-1 infected 10-12 week $\% \mathrm{SJL} / \mathrm{J}, \mathrm{A} / \mathrm{J}$, and PL/J mice were examined every 3 days from day 0 through $30 \mathrm{PI}$. In SJL/J mice, 'focal' areas are few in number and small in size (Figure $4 \mathrm{a} \& 4 \mathrm{~b}$ ) while in PL/J mice the areas are greater in number and larger in size (Figure $4 \mathrm{e} \& 4 \mathrm{f}$ ). In A/J mice the number and size of the 'focal' areas are intermediate between SJ/L and Pl/J mice (Figure 4c \&4d). The number and size of the 'focal' areas also form a hierarchy among the mouse strains.

The number and size of the 'focal' areas of viral antigen positive cells were determined in every fourth 


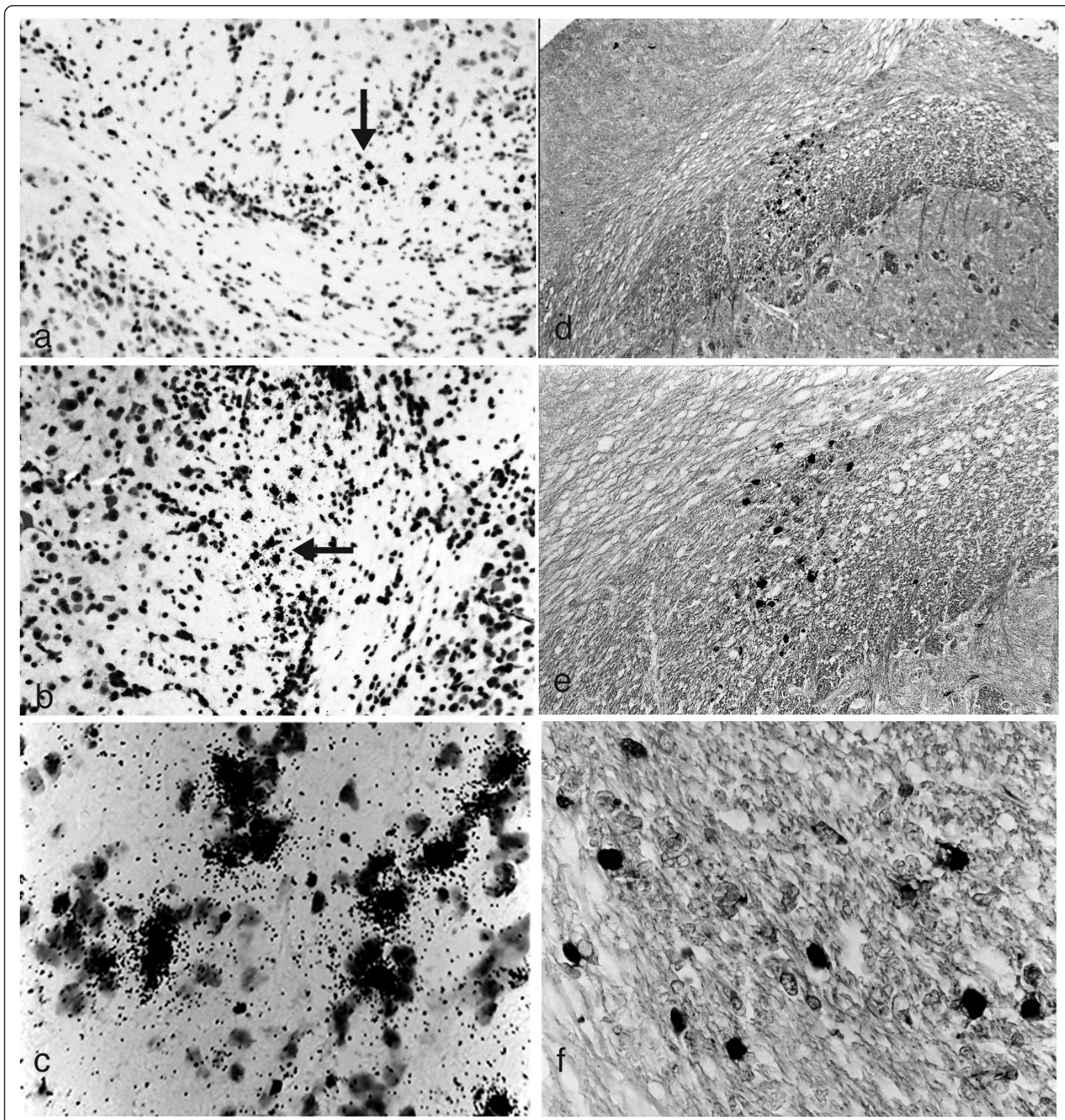

Figure 1 HSV-1 DNA and antigen positive cells are not present diffusely throughout the BST of BL/6 mice but are restricted to an area associated with the RTNBST. Ten-12 week 9 BL/6 mice were infected with HSV-1 strain 2 via the oral mucosa. Three mice were examined every 3 days at necropsy from day 0 through $30 \mathrm{PI}$. Six micron thick serial sections of the brain were examined for ${ }^{35} \mathrm{~S}$-labelled HSV DNA (ISH) and viral antigens (IHC) and counterstained with either $\mathrm{H} \& \mathrm{E}$ or CFV respectively. In representative sections, both viral DNA (Figure 1 $\mathrm{a}-\mathrm{c}$ ) and viral antigen (Figure $1 \mathrm{~d}-\mathrm{f}$ ) are identified on day $3 \mathrm{PI}$ and restricted to a small area of the BST associated with the roots of the trigeminal nerve (RTNBST). (a) Small area of ${ }^{35}$ S-labelled HSV DNA positive cells (arrow) in the BST on day 3 PI (x100) (b) Higher power photomicrograph of HSV-1 DNA positive cells (arrow) on day 3 PI (x200) (c) High power photomicrograph of HSV-1 DNA positive cells on day 3 PI (x400) (d) Small area of HSV-1 antigen positive cells in the BST on day 3 PI (x100) (e) Higher power photomicrograph of HSV-1 antigen positive cells on day $3 \mathrm{PI}$ (x200) (f) High power photomicrograph of HSV-1 antigen positive cells on day $3 \mathrm{PI}$ (x400). 
Table 1 The appearance and clearance of HSV-1 antigen positive cells and 'focal' areas of viral antigen positive cells throughout the brains of inbred strains of mice

\begin{tabular}{|c|c|c|c|c|c|}
\hline \multirow[t]{2}{*}{ Mouse strain ${ }^{a}$} & \multicolumn{4}{|c|}{$\begin{array}{l}\text { Initial appearance of viral } \\
\text { antigen positive } \\
\text { cells throughout the brains }\end{array}$} & \multirow[t]{2}{*}{ Clearance of viral antigen throughout the brain (days $\mathrm{PI}$ ) } \\
\hline & RTNBST $^{\mathrm{b}}$ & $B S T^{c}$ & $C B^{d}$ & $\mathrm{CR}^{\mathrm{e}}$ (days PI) & \\
\hline$\overline{B L / 6}$ & 3 & - & - & - & 12 \\
\hline $\mathrm{BALB} / \mathrm{C}$ & 3 & 3 & 6 & 7 & 18 \\
\hline$\overline{\mathrm{SJL} / \mathrm{J}}$ & 6 & 6 & 7 & 8 & 21 \\
\hline $\mathrm{A} / \mathrm{J}$ & 3 & 3 & 6 & 7 & 21 \\
\hline $\mathrm{PL} / \mathrm{J}$ & 3 & 3 & 5 & 6 & 21 \\
\hline \multirow[t]{2}{*}{ Mouse strain ${ }^{a}$ ext } & \multicolumn{4}{|c|}{$\begin{array}{l}\text { Initial appearance of 'focal' areas of viral antigen positive } \\
\text { cells throughout the brain }\end{array}$} & Clearance of viral antigen throughout the brain (days $\mathrm{PI}$ ) \\
\hline & RTNBST $^{a}$ & $\mathrm{BST}^{\mathrm{b}}$ & $C B^{C}$ & $C R^{d}$ (days PI) & \\
\hline$\overline{B L} / 6$ & - & - & - & - & 12 \\
\hline$\overline{B A L B} / \mathrm{C}$ & 5 & - & - & - & 18 \\
\hline$\overline{\mathrm{SJL} / \mathrm{J}}$ & 9 & 9 & 12 & 15 & 21 \\
\hline $\bar{A} / \mathrm{J}$ & 5 & 5 & 9 & 12 & 21 \\
\hline$\overline{\mathrm{PL} / \mathrm{J}}$ & 5 & 5 & 6 & 9 & 21 \\
\hline
\end{tabular}

${ }^{a}$ Ten-12 week $q$ inbred mice were infected with HSV-1 strain 2 via the oral mucosa. Three mice of each strain were examined every 3 days or as necessary from Day 0 through $30 \mathrm{PI}$

${ }^{\mathrm{b}}$ Roots of the trigeminal nerve in the brainstem

'Brainstem

${ }^{\mathrm{d}}$ Cerebellum

${ }^{\text {e}}$ Cerebral hemispheres

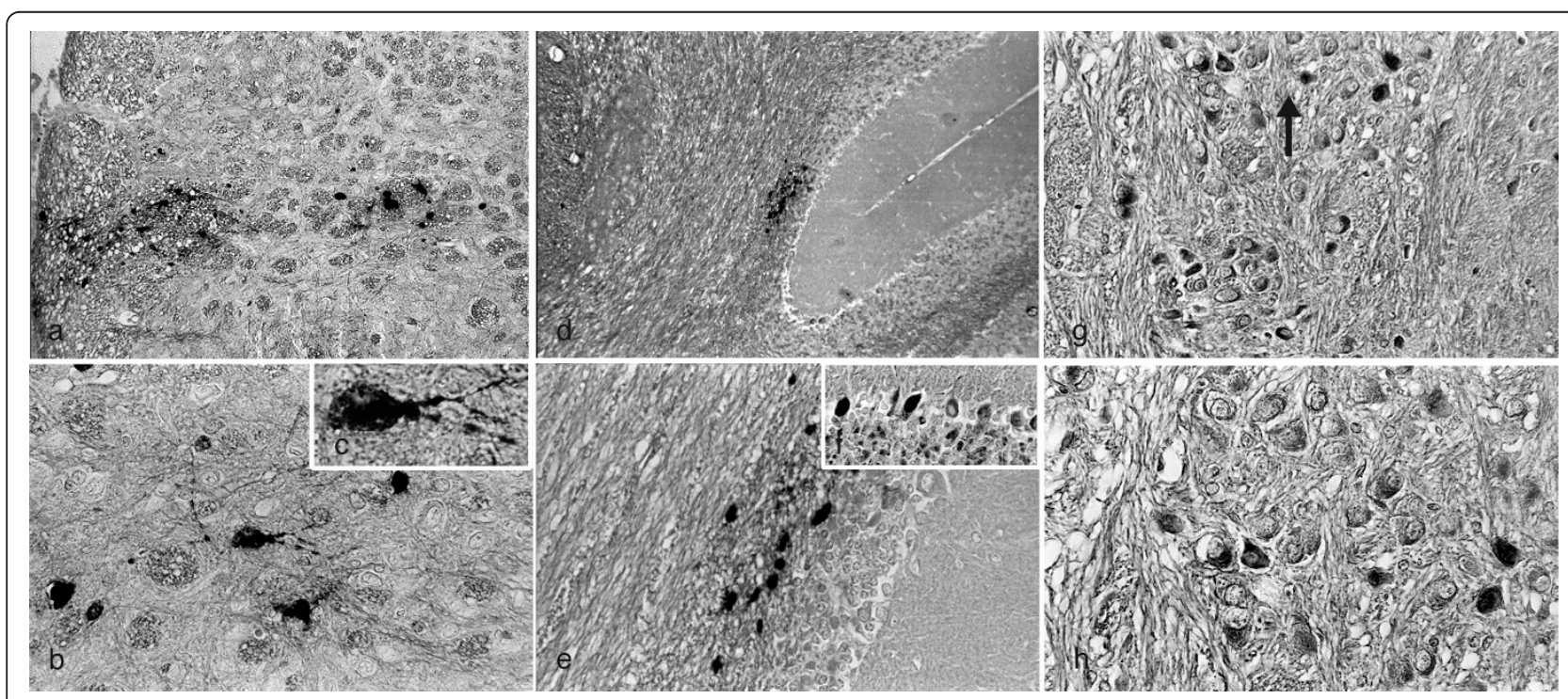

Figure 2 HSV-1 antigen positive cells appear sequentially in non-contiguous areas throughout the brains of BALB/c mice. Ten-12 week o BALB/c mice were infected with HSV-1 strain 2 via the oral mucosa. Three mice were examined every 3 days at necropsy from day 0 through day $30 \mathrm{PI}$. Serial sections of the brain were examined for viral antigens (IHC) and counterstained with CFV. In representative sections, viral antigen was first identified in the BST on day 3 PI. (a) Viral antigen positive cells in the BST, 3 days PI (x100) (b) Higher power photomicrograph of HSV-1 antigen positive cells on day $3 \mathrm{PI}(\times 400)$ (c) High power photomicrograph of HSV-1 antigen positive cell with the morphology of a neuron on day $3 \mathrm{PI}(\mathrm{x} 1000)$. Viral antigen was first identified in the cerebellum (CB) on day 6 PI (d) Viral antigen positive cells in the CB, 6 days PI (x100) (e) Higher power photomicrograph of HSV-1 antigen positive cells on day 6 PI (x400) (f) High power photomicrograph of HSV-1 antigen positive Purkinje cells in the CB, 6 days PI (x400). Viral antigen was first identified in the cerebrum (CR) on day 7 PI (g) Viral antigen positive cells (arrow) in the CR, 7 days PI (x200) (h) Higher power photomicrograph of HSV-1 antigen positive cells with the morphology of neurons in the CR, 7 days PI (X400). 


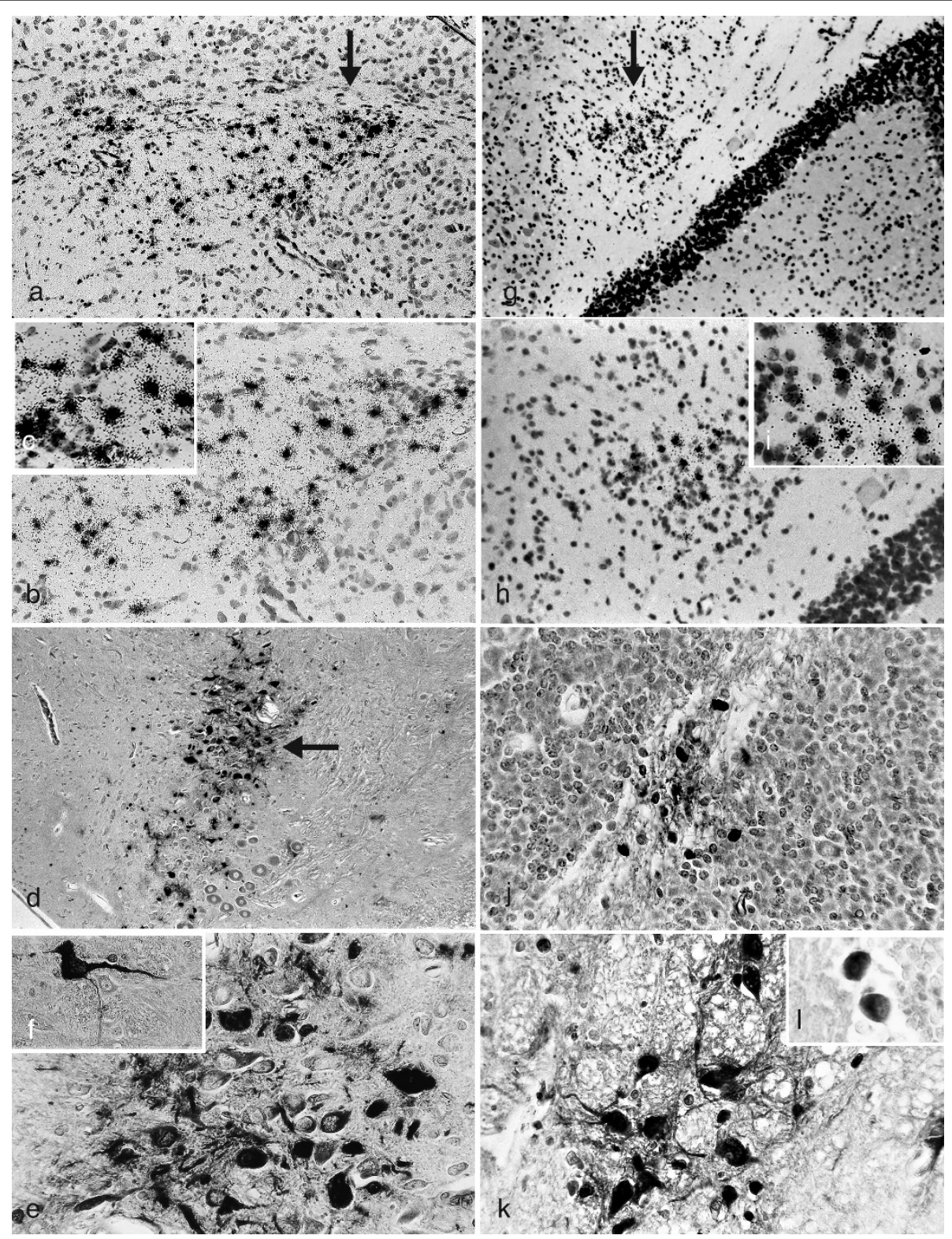

Figure 3 'Focal' areas of HSV-1 DNA and antigen positive cells develop sequentially in non-contiguous areas of the BST and CB of PL/ J mice. Brains from 10-12 week 9 PL/J mice, infected with HSV-1 via the oral mucosa, were examined for viral DNA and antigen. Serial sections of the brain were examined for ${ }^{35}$ S-labelled HSV DNA (ISH) and viral antigens (IHC) and counterstained with either $\mathrm{H} \& \mathrm{E}$ or CFV respectively. 'Focal' areas of ${ }^{35}$ S-labelled HSV-1 DNA (Figure $3 \mathrm{a}-\mathrm{c}$ ) and viral antigen (Figure $3 \mathrm{~d}-\mathrm{f}$ ) positive cells are identified in the BST (a) A 'focal' area of HSV-1 DNA positive cells in the BST (arrow), 3 days PI (x100) (b) Higher power photomicrograph, 3 days PI (x 200) (c) High power photomicrograph, 3 days PI (x400) (d) A 'focal' area of viral antigen positive cells in the BST (arrow), 5 days PI (x100) (e) Higher power photomicrograph, 5 days PI (x400) (f) Higher power photomicrograph of viral antigen positive neuron, 5 days PI ( $\times 400)$. 'Focal' areas of ${ }^{35} \mathrm{~S}$ labelled HSV-1 DNA (Figure 3g-i) and viral antigen (Figure $3 \mathrm{j}-1$ ) positive cells are identified in the CB. (g) A 'focal' area of HSV-1 DNA positive cells in the CB (arrow), 5 days PI (x100) (h) Higher power photomicrograph, 5 days PI (x200) (i) High power photomicrograph, 5 days PI (x400) (j) A 'focal' area of viral antigen positive cells in the CB, 6 days PI (x200) (k) Higher power photomicrograph, 6 days PI (x400) (I) Higher power photomicrograph of viral antigen positive Purkinje cells, 6 days PI ( $\times 400)$.

section of the 140 serial BST-CB sections obtained from each of three mice of the three strains. To allow a comparison between the three mouse strains, IHC sections counterstained with CFV were examined on the first day the 'focal' areas appeared in the BST (day 9 PI in $\mathrm{SJL} / \mathrm{J}$ mice and day $5 \mathrm{PI}$ in $\mathrm{A} / \mathrm{J}$ and $\mathrm{PL} / \mathrm{J}$ mice) and the $\mathrm{CB}$ (day $12 \mathrm{PI}$ in SJL/J mice, day $9 \mathrm{PI}$ in A/J mice, and day $6 \mathrm{PI}$ in PL/J mice) (Table 2). Differences in the 

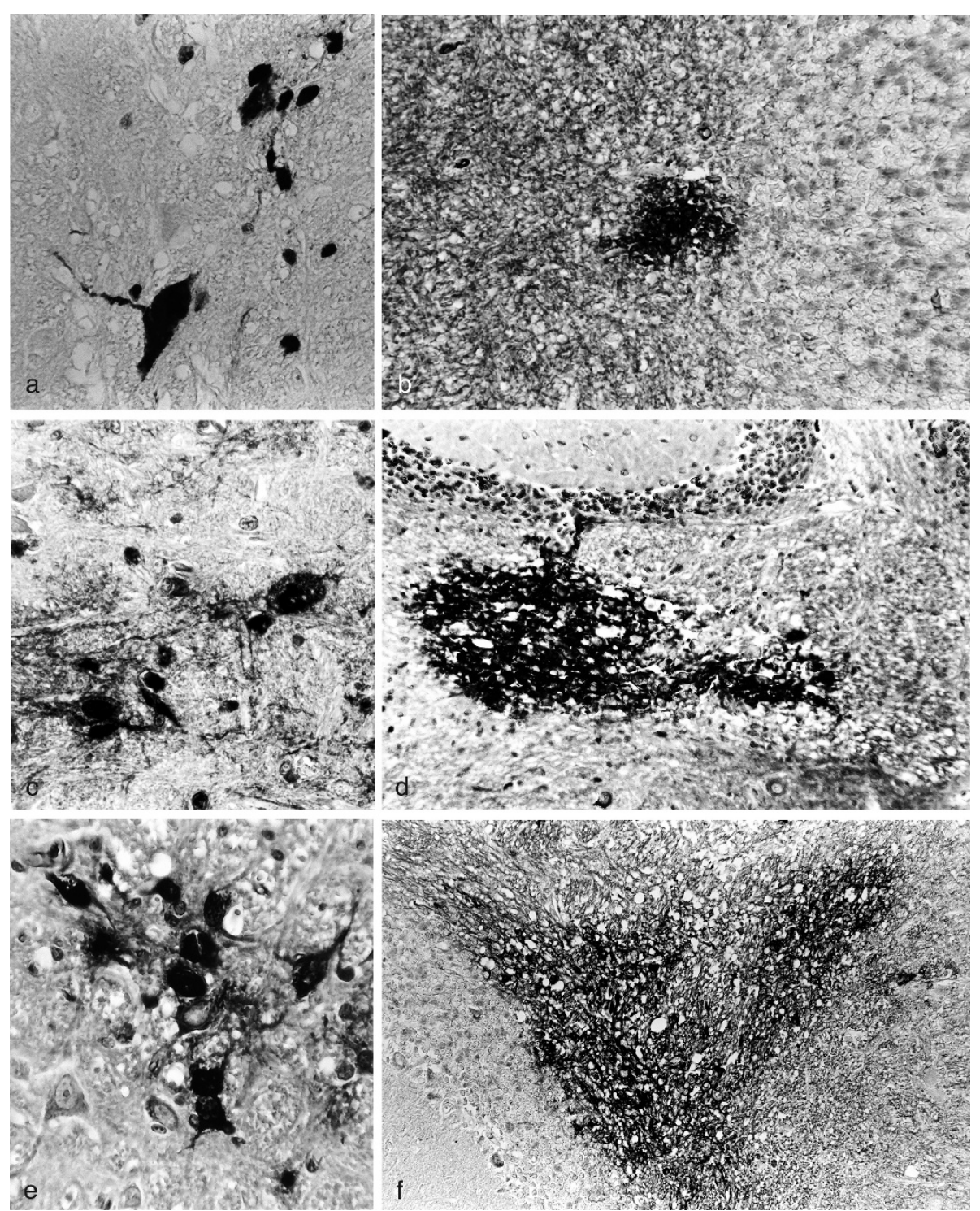

Figure 4 A hierarchy exists among 'focal' areas of HSV-1 antigen positive cells in SJL/J, A/J, and PL/J mice. 'Focal' areas of viral antigen positive cells in serial sections of the BST-CB derived from 3 mice of each strain on day 6,9, 12, and 15 PI were examined. Serial sections were examined by IHC and the number of 'focal' areas of viral antigen in the BST and CB per slide determined. As one 'focal' area could be present in several serial sections, the greatest diameter of the lesion at a magnification of 400x for the BST and 200x for the CB was recorded.

Representative 'focal' areas of HSV-1 antigen positive cells in the BST-CB of virus infected 10-12 week $q$ mice are shown. Representative 'focal' areas in the BST of (a) SJL/J, 9 days PI (x400) (c) A/J, 6 days PI (x400) and (e) PL/J, 6 days PI (x400) mice are shown. Representative 'focal' areas in the CB of (b) SJL/J, 12 days PI (x200) (d) A/J, 9 days PI (x200) and (f) PL/J, 6 days PI (x200) mice are also shown.

number and size of the 'focal' areas among the three strains were statistically significant (Table 2).

Demyelinating lesions co-localize with 'focal' areas of HSV-1 antigen positive cells throughout the brains of $\mathrm{SJL} / \mathrm{J}, \mathrm{A} / \mathrm{J}$, and PL/J mice

The relationship between 'focal' areas of HSV-1 antigen positive neuronal and non-neuronal cells and demyelinating lesions throughout the brain was determined by IHC in sections counterstained with LFV-CFV. HSV-1 infected
10-12 week O SJL/J, A/J, and PL/J mice were examined every 3 days from day 0 through 30 PI. Initially, islands of demyelination develop either adjacent to or within 'focal' areas of viral antigen positive cells (Figure 5a \&5b). As viral antigen is cleared, the 'focal' areas decrease in size while the demyelinating lesions increase in size (Figure 5c $\& 5 \mathrm{~d})$. Further, viral antigen positive cells in the demyelinating lesions decrease in number and are eventually cleared (Figure 5e \&5f). Viral antigen is cleared throughout the brain in all mouse strains by day 21 PI (Table 1 ). 
Table 2 The number and size of 'focal' areas of HSV-1 antigen positive cells in the BST-CB of inbred strains of mice

\begin{tabular}{|c|c|c|c|c|c|c|}
\hline \multirow{2}{*}{$\begin{array}{l}\begin{array}{l}\text { Mouse } \\
\text { strain }^{\text {a }}\end{array} \\
\text { SJL/J }\end{array}$} & \multirow{2}{*}{$\begin{array}{c}\text { BST }^{\mathbf{b}} \text { examined for focal' areas on day } \\
\text { (PI) }\end{array}$} & \multirow{2}{*}{$\begin{array}{c}\mathrm{CB}^{\mathrm{C}} \text { examined for 'focal' areas on day } \\
(\mathrm{PI})\end{array}$} & \multicolumn{2}{|c|}{$\begin{array}{l}\text { \# of 'focal' areas } \\
\text { per section }\end{array}$} & \multicolumn{2}{|c|}{$\begin{array}{c}\text { Size of 'focal' } \\
\text { area }^{e}(\mu \mathrm{m})\end{array}$} \\
\hline & & & $\begin{array}{c}0.6 \pm \\
0.7\end{array}$ & $\begin{array}{l}0.7 \pm \\
0.7\end{array}$ & $97 \pm 8$ & $153 \pm 6$ \\
\hline$A / J$ & 5 & 9 & $\begin{array}{c}0.7 \pm \\
0.8\end{array}$ & $\begin{array}{c}2.6 \pm \\
1.0\end{array}$ & $156 \pm 8$ & $285 \pm 9$ \\
\hline $\mathrm{PL} / \mathrm{J}$ & 5 & 6 & $\begin{array}{c}1.6 \pm \\
1.0\end{array}$ & $\begin{array}{c}4.6 \pm \\
1.7\end{array}$ & $\begin{array}{l}207 \pm \\
15\end{array}$ & $\begin{array}{c}373 \pm \\
21\end{array}$ \\
\hline
\end{tabular}

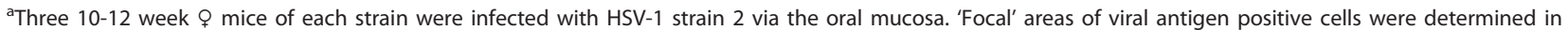
serial sections of the brainstem-cerebellum (BST-CB) by IHC and CFV counterstain.

bSections of the BST were examined on the first day that 'focal' areas appear for each mouse strain.

'Sections of the CB were examined on the first day that 'focal' areas appear for each mouse strain.

${ }^{d}$ Average number of 'focal' areas of viral antigen \pm SD per section. Differences among mouse strains are all statistically significant at $P<0.001$ except for the difference between SJL/J and A/J BST which was NS.

${ }^{\text {e}}$ As a single 'focal' area could be represented in several sections, the greatest diameter for each'focal' area was determined. The average diameter \pm SD of the 'focal' areas for the three mouse strains was then calculated. Differences between the three mouse strains are all statistically significant at $P<0.001$.

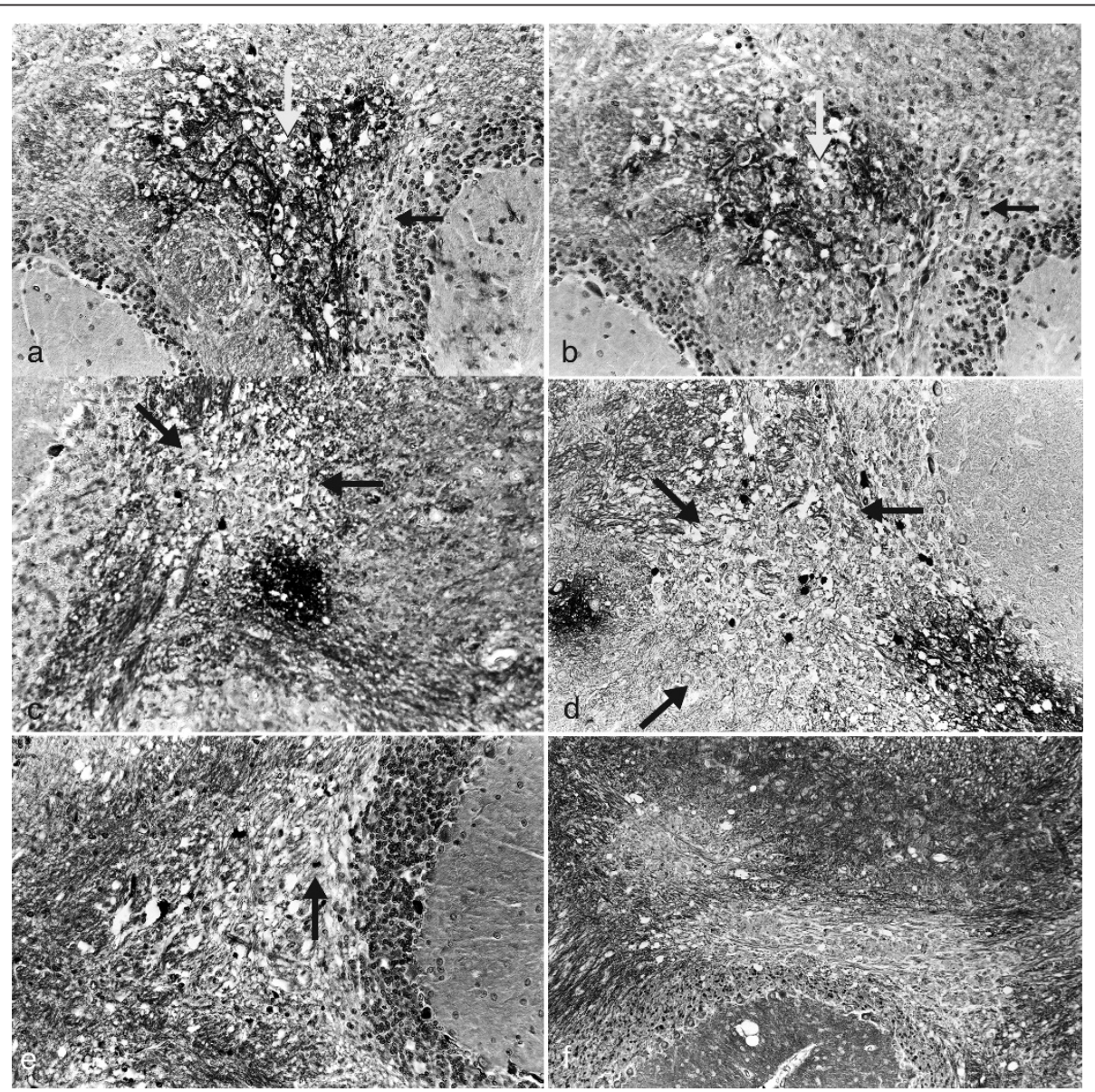

Figure 5 'Focal' areas of HSV-1 antigen positive cells and demyelinating lesions co-localize throughout the brains of SJL/J, A/J, and $\mathrm{PL} / \mathrm{J}$ mice. Serial IHC sections counterstained with LFB-CFV were examined for 'focal' areas of viral antigen positive cells and CNS demyelination in the BST and CB. 'Focal' areas and demyelinating lesions co-localize throughout the brains of 10-12 week o SJL/J, A/J, and PL/J mice infected with HSV-1 via the oral mucosa. Initially, island of demyelination are identified within or adjacent to 'focal' areas of viral antigen. Representative sections from the CB of PL/J mice identify these areas within (white arrow) or adjacent to (black arrow) 'focal' areas of viral antigen (a) 8 days PI ( $\times 200)$ and (b) 9 days PI ( $\times 200)$. As the 'focal' areas of viral antigen are cleared, the demyelinating lesions increase in size. Representative sections from the CB of SJL/J mice identify areas of demyelination (arrows) adjacent to 'focal' areas of viral antigen (c) 14 days PI (x200) and (d) 15 days PI (x200). Although individual antigen positive cells can remain in the demyelinating lesions for a period of time (e) antigen positive cell (arrow) in the CB of PL/J mouse, 18 days PI ( $\times 200)$, 'focal' areas of viral antigen are eventually cleared (f) demyelinating lesions in the CB of PL/J mouse, 20 days PI (x200). 
The relationship between 'focal' areas of HSV-1 antigen positive cells and demyelinating lesions was determined in every fourth section of the 140 serial BST-CB sections obtained from each of three mice of the three strains. To allow a comparison between the three mouse strains, IHC sections counterstained with LFB-CFV were examined on the first day demyelinating lesions appeared in the BST (day $12 \mathrm{PI}$ in SJL/J mice and day $6 \mathrm{PI}$ in A/J and $\mathrm{PL} / \mathrm{J}$ mice) and the $\mathrm{CB}$ (day $15 \mathrm{PI}$ in SJL/J mice, day $12 \mathrm{PI}$ in $\mathrm{A} / \mathrm{J}$ mice, and day $9 \mathrm{PI}$ in PL/J mice) (Table 3 ). Although the number of 'focal' areas of antigen positive cells and demyelinating lesions is mouse strain dependent (Table 3), in all mouse strains, the percentage of demyelinating lesions that co-localize with 'focal' areas of viral antigen is greater than $90 \%$. Not all 'focal' areas of viral antigen co-localized with demyelinating lesions. Either the demyelinating lesions have yet to develop in relation to the 'focal' areas of viral antigen positive cells or not all 'focal' areas are associated with demyelinating lesions.

\section{Despite the clearance of viral antigen positive cells, HSV-1 DNA positive cells can remain in demyelinating lesions of $\mathrm{SJ} / \mathrm{J}, \mathrm{A} / \mathrm{J}$, and $\mathrm{PL} / \mathrm{J}$ mice}

Infection of mice with HSV-1 can result in the development of viral latency in the CNS [8-10]. The relationship between ${ }^{35}$ S-labelled HSV-1 DNA positive cells and CNS demyelinating lesions was examined in adjacent serial sections of the BST-CB using histology and ISH. HSV-1 infected 10-12 week $\mathrm{S} \mathrm{SJ} / \mathrm{J}, \mathrm{A} / \mathrm{J}$, and PL/J mice were examined every 3 days from day 0 through $30 \mathrm{PI}$. Although infectious virus [34] and viral antigen (Table 1) are eventually cleared from the brains of all three mouse strains, the clearance of infectious virus precedes that of viral antigen. In contrast, HSV-1 DNA positive cells can remain in the brain beyond 25 days PI and are identified in demyelinating lesions of all three strains (Figure 6). This is consistent with latently infected cells remaining in an area of demyelination.

\section{Discussion}

Mice infected with HSV-1 can develop CNS demyelinating lesions [24-32] but their development is determined by a number of factors including route of infection and virus strain. When infected in the pinna of the ear, BALB/cAJcl mice develop demyelination restricted to the descending root of the facial nerve [32]. When infected with the Rodanus strain of HSV-1, both Swiss and BALB/c mice develop demyelination restricted to the TREZ [24-27] but when infected with Roziman strain F, demyelination develops in both the TREZ and BST of the two mouse strains [28-31]. In contrast, BALB/c mice infected with a $\mathrm{HSV}-1$ recombinant virus expressing IL-2 develop lesions in the optic nerve, brain, and spinal cord $[38,39]$. Further, BALB/c mice infected with strains McKrae or KOS [38-40] or BL/6 mice infected with strain McRae [40] do not develop CNS demyelination but macrophage depleted BALB/c and $\mathrm{BL} / 6$ mice, infected with strain KOS or McKrae respectively, do develop lesions throughout the CNS [40]. A number of studies performed by Ghiasi and colleagues have implicated $\mathrm{CD} 4{ }^{+} \mathrm{CD} 25^{+} \mathrm{FoxP}_{3}{ }^{+} \mathrm{T}$ cells as playing a pathogenic role in the development of demyelinating lesions when Il-12 p70 macrophages are ablated [40].

Mouse strain can also influence the development of HSV-1 induced CNS demyelination. We previously reported that $\mathrm{SJL} / \mathrm{J}, \mathrm{A} / \mathrm{J}$, and $\mathrm{PL} / \mathrm{J}$ but not $\mathrm{BL} / 6$ mice, infected with a sub-lethal dose of HSV-1 strain 2 via the oral mucosa, develop demyelinating lesions throughout the brain while lesions in BALB/c mice are restricted to the TREZ of the BST $[33,34]$. The lesions are characterized by demyelination, a mononuclear cell infiltrate, and relative preservation of axons $[33,34,41]$. Further, SJL/J,

Table 3 The relationship between 'focal' areas of HSV-1 antigen and demyelinating lesions in the BST-CB of inbred strains of mice

\begin{tabular}{|c|c|c|c|c|c|c|c|c|}
\hline \multirow[t]{2}{*}{ Mouse strain ${ }^{a}$} & \multirow[t]{2}{*}{$\mathrm{BST}^{\mathrm{b}}$ on day (PI) } & \multirow[t]{2}{*}{$\begin{array}{l}\mathrm{CB}^{\mathrm{C}} \text { on } \\
\text { day }(\mathrm{PI})\end{array}$} & & \multirow{2}{*}{$\begin{array}{l}\text { \# of 'focal' } \\
\text { areas }^{d}\end{array}$} & \multicolumn{2}{|c|}{$\#$ of lesions ${ }^{e}$} & \multicolumn{2}{|c|}{$\begin{array}{l}\text { \% of 'focal' areas } \\
\text { that co-localize with lesions }\end{array}$} \\
\hline & & & BST & & BST & $C B$ & BST & $C B$ \\
\hline SJL/J & 12 & 15 & $19.7 \pm 1.5$ & $25.5 \pm 4.1$ & $18.2 \pm 1.0$ & $24.0 \pm 3.7$ & 92 & 94 \\
\hline $\mathrm{A} / \mathrm{J}$ & 6 & 12 & $24.8 \pm 2.0$ & $93.7 \pm 1.1$ & $24.1 \pm 1.8$ & $90.6 \pm 1.0$ & 97 & 97 \\
\hline $\mathrm{PL} / \mathrm{J}$ & 6 & 9 & $56.7 \pm 3.1$ & $163.7 \pm 7.4$ & $53.4 \pm 2.1$ & $162.4 \pm 6.0$ & 94 & 99 \\
\hline
\end{tabular}

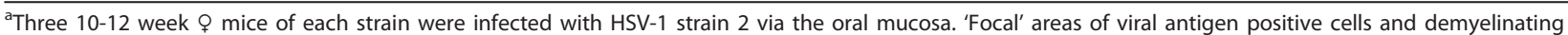
lesions were determined in serial sections of the brainstem-cerebellum (BST-CB) by IHC and LFB-CFV counterstain.

bBoth 'focal' areas of viral antigen and demyelinating lesions were determined in the BST of all three mouse strains. Sections of the BST were obtained on the first day demyelinating lesions appear in that mouse strain [24].

'Both 'focal' areas of viral antigen and demyelinating lesions were determined in the CB of all three mouse strains. Sections of the CB were obtained on the first day demyelinating lesions appear in that mouse strain [24].

'Average number of 'focal' areas of viral antigen \pm SD in the BST and CB of each of three mice. Differences among mouse strains are all statistically significant at $P<0.005$.

${ }^{\mathrm{e}}$ Average number of demyelinating lesions \pm SD among in the BST and CB of each of three mice. Differences among mouse strains are all statistically significant at $\mathrm{P}<0.005$. 


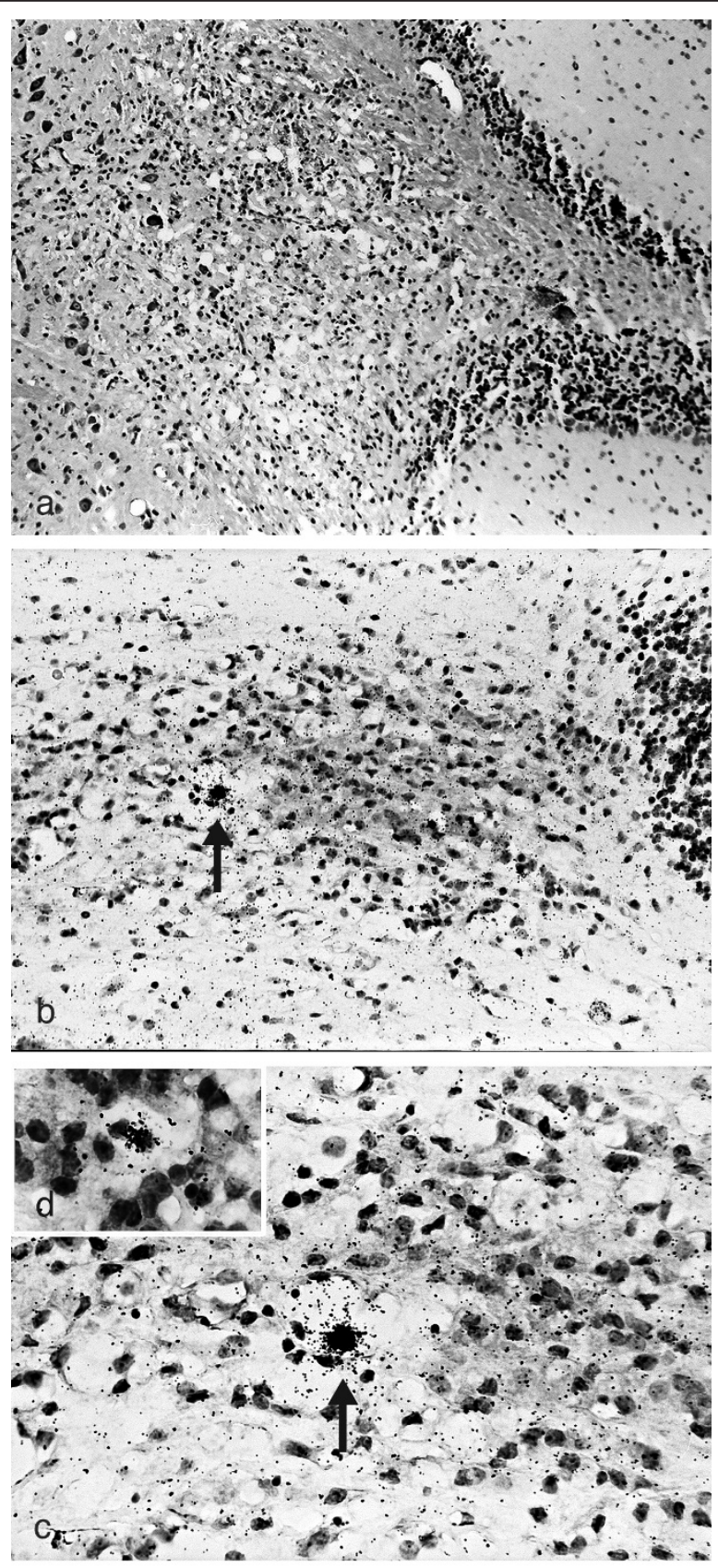

Figure $6 \mathrm{HSV}-1$ DNA positive cells remain in an area of demyelination following the clearance of viral antigen. ${ }^{35}$ S-labelled HSV-1 DNA positive cells can remain in demyelinating lesions of 10-12 week $\mathrm{OSJL} / \mathrm{J}, \mathrm{A} / \mathrm{J}$, and PL/J mice infected with virus via the oral mucosa. Adjacent serial sections were examined by ISH and histology. In representative sections from the CB of HSV-1 infected PL/J mice (a) demyelinating lesion are identified, 26 days PI, (x100), LFB-CFV while adjacent sections identify (b) HSV-1 DNA positive cells (arrow), 26 days Pl, (x200), ISH counterstained with H \& E. (c) Higher power photo-micrograph of HSV-1 DNA positive cells (arrow), 26 days Pl, (x400), ISH/H \& E. (d) High power photo-micrograph of HSV-1 DNA positive cell, 26 days PI (x1000), ISH/H \& E.

$\mathrm{A} / \mathrm{J}$, and PL/J mice develop lesions sequentially throughout the brain during the early stage $(<24$ days PI), but randomly in both $\mathrm{A} / \mathrm{J}$ and $\mathrm{PL} / \mathrm{J}$ mice during the intermediate stage (1-3 months PI), and only in PL/J mice during the late stage ( $>3$ months PI) of demyelination
[34]. During the early stage of demyelination, lesions are immune mediated [42], and their appearance correlates with the sequential spread of infectious virus throughout the brain $[33,37]$. The number and size of the lesions follow a hierarchical order among the mouse strains 
$[33,34]$. Although the influence of mouse strain on CNS infection is recognized and defined for a number of different viruses [43-46], our understanding of this effect on HSV-1 CNS infection, including the development of demyelination, is at a preliminary stage.

In this study we combine histology, IHC, and ISH to further define the effect of mouse strain on the development of early stage demyelination in mice infected with HSV-1 strain 2 via the oral mucosa.

Results of this study argue that HSV-1 induced CNS demyelination throughout the brain in susceptible strains of mice, develops in several stages. First, viral DNA and antigen positive cells appear sequentially throughout the brain, localize to non-contiguous areas of the brain, and primarily to cells with the morphology of neurons (Table 1). This is consistent with previous reports on the spread and localization of HSV-1 in the brain [47-49] resulting from transneuronal transport of virus from the periphery to the CNS and synaptically determined relationships in the CNS [30,49-52]. However, results of this study indicate that this does not occur in all mouse strains. Although it is the case in $\mathrm{BALB} / \mathrm{c}, \mathrm{SJL} / \mathrm{J}, \mathrm{A} / \mathrm{J}$, and $\mathrm{PL} / \mathrm{J}$ mice, it is not in $\mathrm{BL} / 6$ mice where viral DNA and antigen are restricted to a specific area of the BST. The restriction of HSV-1 to the BST in this strain was previously identified by viral titration studies [37] but the results of this study indicate a far greater degree of restriction occurs in the BST then was previously recognized.

Second, 'focal' areas of viral antigen positive neuronal and non-neuronal cells develop throughout the brain (Table 1). The areas appear sequentially and localize to non-contiguous areas throughout the brain. Their development may result from the uptake and replication of HSV-1 in neurons resulting in the degeneration of infected cells, loss of cellular integrity, and release of virus [53-56]. Having a high affinity for herpes viruses [57-59], glia can become infected in areas surrounding the disintegrating neurons $[28,31]$. Further, the development of 'focal' areas of viral antigen with HSV-1 has similarities to other herpes virus infections including pseudorabies virus where reactive gliosis and macrophage infiltration provides a barrier to the diffusion of virus through the extra-cellular compartment by isolating and phagocytosing virus $[60,61]$. Results of our study identify 'focal' areas of viral antigen positive cells throughout the brains of SJL/J, A/J, and PL/J mice but not in BALB/C mice where the 'focal' areas are restricted to small areas of the BST. In BL/6 mice 'focal' areas of viral antigen positive cells do not develop in the brain. In the strains developing 'focal' areas of viral antigen positive cells throughout the brain, there is a hierarchical order for size and number. Lesions are numerous and large in PL/J mice but few in number and small in size in SJL/J mice.
A/J mice are intermediate for both number and size. The differences are statistically significant (Table 2). Previous studies have attributed differences in mouse strain susceptibility to the extent of glial infection with HSV-1 $[33,41,62,63]$ while other studies have reported differences in resistance to HSV-1to be mediated directly by glial cells $[31,64,65]$. A similar hierarchical order was previously identified for number and size of demyelinating lesions developing in the same strains of mice [34].

Third, 'focal' areas of viral antigen positive cells co-localize with demyelinating lesions that develop throughout the brain (Table 3). While the co-localization of 'focal' areas with demyelinating lesions occurs in SJL/J, A/J, and $\mathrm{PL} / \mathrm{J}$ mice, they are restricted to a small area of the BST of $\mathrm{BALB} / \mathrm{c}$ mice, and do not develop in BL/6 mice. Although the results argue that demyelinating lesions evolve from 'focal' areas of antigen positive cells, it is unclear if they develop from within or adjacent to the 'focal' areas.

Fourth, as 'focal' areas and individual viral antigen positive cells are cleared from the lesions, viral DNA positive cells, consistent with a latent infection, remain in the demyelinating lesions. Although viral latency in the CNS of mice is reported after infection with HSV-1 [8-10], the presence of latent virus within demyelinating lesions of mice has not been previously reported to our knowledge.

Based on these results, we argue that the effect of mouse strain on the development of CNS demyelination during the early stage of HSV-1infection $(<24$ days PI) is determined by the ability of virus to spread through the PNS and CNS of a specific mouse strain and the ability of the host to mount an immune response that restricts viral spread and clears virus from the brain. In all mouse strains infected with HSV-1 via the oral mucosa, virus spreads via retrograde axonal transport to the TG of the PNS $[1,2]$ and is followed by access to the CNS. In a number but not all mouse strains, virus spreads by transneuronal transport throughout the brain with the development of focal and non-contiguous neuronal infection determined by synaptically defined relationships in the CNS [30,49-52]. In many but not all mouse strains, this is followed by the development of 'focal' areas of antigen positive neuronal and nonneuronal cells that result from the replication of virus in neurons, degeneration of infected cells, release of virus [53-56], and subsequent infection of surrounding glia [57-59]. The hierarchical order of number and size of 'focal' areas reflects mouse strain differences in resistance of glia to HSV-1 $[33,41,64,65]$. An immune response clears 'focal' areas of viral antigen positive cells from the CNS but results in the development of demyelinating lesions [42]. In A/J, PL/J, and SJL/J mice, viral antigen appears early throughout the brain but viral clearance is delayed until day 21 PI (Table 1). A delay in the development of an immune response in these mouse strains could explain the delay in viral clearance and allow for the development 
of 'focal' areas of antigen positive neuronal and non-neuronal cells. In BL/6 mice, viral antigen also appears early in the CNS but in contrast to other mouse strains, virus is restricted to the BST. The restriction of viral spread and the failure to develop 'focal' areas of viral antigen positive cells is likely responsible for the absence of demyelinating lesions. Recently, we provided evidence that the restriction of viral spread in BL/6 mice results from redundancy in the immune system and mediated by NK/NKT and CD8 ${ }^{+}$ T-lymphocytes [37]. Further, clearance of viral antigen from the brains of $\mathrm{BL} / 6$ mice occurs on day $12 \mathrm{PI}$; earlier then occurs in other mouse strains (Table 1). The immune mechanisms mediating the clearance of virus has not yet been defined. In BALB/c mice, viral antigen also appears early throughout the brain (Table 1 ) but in this strain viral clearance occurs by day $18 \mathrm{PI}$. This is delayed compared to $\mathrm{BL} / 6$ mice but early when compared to $\mathrm{SJL} / \mathrm{J}, \mathrm{A} / \mathrm{J}$, and $\mathrm{PL} / \mathrm{J}$ mice. The delay in clearance could explain the spread of virus throughout the brain but when compared to SJL/J, $\mathrm{A} / \mathrm{J}$, and $\mathrm{PL} / \mathrm{J}$ mice, might be sufficient to clear virus before 'focal' areas of viral antigen positive cells develop.

\section{Conclusions}

When infected with a sub-lethal dose of HSV-1 lab strain 2 via the oral mucosa, susceptible SJL/J, A/J, and PL/J mice develop demyelinating lesions throughout the brain. In contrast, in moderately resistant BALB/c mice, demyelinating lesions are restricted to the TREZ of the BST. Resistant BL/6 mice do not develop CNS demyelination. In this study, we combine histology, IHC, and ISH to further investigate the effect of mouse strain on the early stage of demyelination $(<24$ days PI).

Results of this study indicate that demyelinating lesions throughout the brain of susceptible mice develop in several stages. Initially, viral DNA and antigen infected cells, largely neurons, appear in non-contiguous areas throughout the brain. This is followed by the development of 'focal' areas of viral antigen positive neuronal and nonneuronal cells in non-contiguous areas throughout the brain. The number and size of the 'focal' areas follow a hierarchical order among the different mouse strains. Next, the 'focal' areas of viral antigen positive cells are seen to co-localize with demyelinating lesions suggesting they evolve from the 'focal' areas. As viral antigen positive cells and 'focal' areas are cleared, viral DNA positive cells consistent with a latent infection can remain in the areas of demyelination. All of these stages occur in susceptible $\mathrm{SJL} / \mathrm{J}, \mathrm{A} / \mathrm{J}$, and $\mathrm{PL} / \mathrm{J}$ mice but not in moderately resistant $\mathrm{BALB} / \mathrm{c}$ mice where 'focal' areas of antigen positive cells are restricted to a small area of the BST, and not in resistant BL/6 mice where 'focal' areas do not develop in the brain.

We hypothesize that the development of demyelinating lesions throughout the brain of susceptible mouse strains results from the non-contiguous spread of virus throughout the brain and the inability of the host to either restrict viral spread or clear virus from the brain prior to the development of 'focal' areas of viral antigen positive neuronal and non-neuronal cells.

\section{Abbreviatons}

BL/6: C57BL/6; BST: Brainstem; CB: Cerebellum; CNS: Central nervous system; CR: Cerebral hemispheres; HSV: Herpes simplex virus; HSV-1: Herpes simplex virus type 1; IHC: Immunohistochemistry; ISH: In-situ hybridization; MS: Multiple sclerosis; PAP: Peroxidase-antiperoxidase; PBS: Phosphate buffered saline; PCR: Polymerase chain reaction; PFU: Plaque forming units; PI: Post infection; PNS: Peripheral nervous system; RTNBST: Roots of the trigeminal nerve in the brainstem; TG: Trigeminal ganglia; TREZ: Trigeminal route entry zone

\section{Author details}

${ }^{1}$ Department of Medicine, University of British Columbia, Vancouver V6T 1Z3, Canada. ${ }^{2}$ Department of Pathology, British Columbia's Children's Hospital, Vancouver V6H 3 V4, Canada.

\section{Authors' contributions}

ASL carried out the histology, immunohistochemistry, and in-situ hybridization studies. EET was a major participant in the design and coordination of this study. LFK conceived the study, participiated in its design and coordination and undertook a number of the studies, assisted by ASL. All authors read and approved the final manuscript.

\section{Competing interests}

The authors declare that they have no competing interests.

Received: 9 July 2011 Accepted: 26 March 2012

Published: 26 March 2012

\section{References}

1. Roizman B, Knipe DM: Herpes simplex viruses and their replication. In Fields Virology.. 4 edition. Edited by: Knipe DM, Howley PM, Griffen DE. Philadelphia, PA: Lippincott Williams 2001:2399-2459.

2. Whitley RJ: Herpes simplex viruses. In Fields Virology.. 4 edition. Edited by: Knipe DM, Howley PM, Griffen DE. Philadelphia, PA: Lippincott Williams 2001:2461-2509.

3. Gilden DH, Gesser R, Smith J, Wellish M, Laguardia JL, Cohrs RJ, Mahalingam R: Presence of VZV and HSV-1 DNA in human nodose and celiac ganglia. Virus Genes 2001, 23:145-147.

4. Stevens JG, Cook ML: Latent herpes simplex virus in spinal ganglia of mice. Science 1971, 173:843-845.

5. Baringer JR, Pisani P: Herpes simplex virus (HSV) nucleic acid in the central nervous system of man. Ann Neurol 1994, 26:283-287.

6. Fraser NW, Lawrence WC, Wroblewska Z, Gilden DH, Koprowski H: Herpes simplex type 1 DNA in human brain tissue. PNAS (USA) 1981, 78:6461-6465.

7. Sequiera LW, Carrasco LH, Curry A, Jennings LC, Lord MA, Sutton RNP: Detection of Herpes simplex viral genes in brain tissue. Lancet 1979, 314:609-612

8. Cabrera CV, Wohlensky C, Openshaw H, Rey-Mendez M, Puga A, Notkins AL: Herpes simplex virus DNA sequences in the CNS of latently infected mice. Nature 1980, 88:288-290.

9. Drommond CWE, Eglin RP, Esiri MM: Herpes simplex virus encephalitis in a mouse model: PCR evidence for CNS latency following acute infection. J Neurol Sci 1994, 127:159-163.

10. Rock DL, Fraser NW: Detection of HSV-1 genes in the CNS of latently infected mice. Nature 1983, 302:523-525. 
11. Roos KL: Encephalitis. Neurol Clin 1999, 17:813-833.

12. Whitley RJ, Kimberlin DW, Roizman B: Herpes simplex viruses. Clin Infect Dis 1988, 26:541-555.

13. Kennedy PG: Viral encephalitis. J Neurol 2005, 252:268-272.

14. Lopez C: Genetics of natural resistance to herpesvirus infections in mice. Nature 1975, 258:152-153.

15. Kastrukoff LF, Lau AS, Puterman ML: Genetics of natural resistance to Herpes simplex virus 1 (HSV 1) latent infection of the peripheral nervous system in mice. J Gen Virol 1986, 67:613-621.

16. Bergstrom $T$, Anderson $O$, Vahlne A: Isolation of Herpes simplex virus type 1 during the first attack of multiple sclerosis. Ann Neurol 1989, 26:283-285.

17. Christenson T: Human herpesviruses in MS. Int MS J 2007, 14:41-47.

18. Martin JR: Herpes simplex virus types 1 and 2 and multiple sclerosis. Lancet 1981, 318:777-781.

19. Martin JR, Holt RK, Webster H, de F: Herpes simplex related antigen in human demyelinating disease and encephalitis. Acta Neuropathol 1988, 76:325-327.

20. Simmons A: Herpesviruses and multiple sclerosis. Herpes 2001, 8:60-63.

21. Sanders VJ, Felisan S, Waddell A, Tourtellotte WW: Detection of Herpesviridae in postmortem multiple sclerosis brain tissue and controls by polymerase chain reaction. J Neurovirol 1996, 2:249-258.

22. Sanders VJ, Waddell AE, Felisan SL, Li X, Conrad AJ, Tourtellotte WW: Herpes simplex virus in postmortem multiple sclerosis brain tissue. Arch Neurol 1996, 53:125-133.

23. Waubant E, Mowry E, Krupp L, Chitnis T, Kuntz N, Ness J, Strober J, Belman A, Milazzo M, Gorman M, Weinstock-Guttman B, Rodriguez M, Oksenberg J, James J: Infections with CMV and, in those HLA-DRB1*15 positive, HSV-1, are associated with a lower risk of pediatric-onset MS [abstract]. Neurology 2011, 76:A396.

24. Townsend JJ: The demyelinating effect of corneal HSV infection in normal and nude (athymic) mice. J Neurol Sci 1981, 50:435-441.

25. Townsend JJ: The relationship of astrocytes and macrophages to CNS demyelination after experimental Herpes simplex virus infection. J Neuropath Exp Neurol 1981, 40:369-379.

26. Townsend JJ: Macrophage response to herpes simplex encephalitis in immune competent and T cell-deficient mice. J Neuroimmunol 1985, 7:195-206.

27. Townsend JJ, Baringer JR: Morphology of central nervous system disease in immunosuppressed mice after peripheral herpes simplex virus inoculation: trigeminal root entry zone. Lab Invest 1979, 40:178-182.

28. Itoyama Y, Sekizawa T, Openshaw H, Kogure K, Goto I: Early loss of astrocytes in herpes simplex virus-induced central nervous system demyelination. Ann Neurol 1991, 29:285-292

29. Kristensson K, Vahlne A, Persson LA, Lycke E: Neural spread of herpes simplex virus types 1 and 2 in mice after corneal or subcutaneous (footpad) inoculation. J Neurol Sci 1978, 35:331-340.

30. Kristensson K, Svennerholm B, Persson L, Vahlne A, Lycke E: Latent herpes simplex virus trigeminal ganglionic infection in mice and demyelination in the central nervous system. J Neurol Sci 1979, 43:253-264.

31. Kristensson K, Svennerholm B, Lycke E: Herpes simplex virus induced demyelination. J Neurol Sci 1983, 60:247-252.

32. Wakisaka H, Nato N, Honda N, Takahaski H, Kisaki H, Murakami S, Gyo K, Moninoki K, Kobayashi N, Matsuda S: Demyelination associated with HSV1-induced facial paralysis. Exp Neurol 2002, 178:68-79.

33. Kastrukoff LF, Lau AS, Kim SU: Multifocal CNS demyelination following peripheral inoculation with herpes simplex virus type 1. Ann Neurol 1987, 22:52-59.

34. Kastrukoff LF, Lau AS, Leung GY, Walker D, Thomas EE: Herpes simplex virus type 1 (HSV 1) induced multifocal central nervous system (CNS) demyelination in mice. J Neuropathol Exp Neurol 1992, 51:432-439.

35. Kastrukoff LF, Hamada T, Schumacher U, Long C, Doherty PC, Koprowski H: Central nervous system infection, latency, and immune responses in herpes simplex virus type 1 infections in mice. J Neuroimmunol 1982, 2:295-305.

36. Kastrukoff LF, Long C, Doherty P, Wroblewska Z, Koprowski H: Isolation of virus from brain following immunosuppression of mice with latent herpes simplex virus. Nature 1981, 291:432-433.

37. Kastrukoff LF, Lau AS, Takei F, Smyth MJ, Jones CM, Clarke SRM, Carbone FR Redundancy in the immune system restricts the spread of HSV-1 in the central nervous system (CNS) of C57BL/6 mice. Virology 2010, 400:248-258.

38. Osorio Y, La Point SF, Nusinowitz S, Hofman FM, Ghiasi H: CD8 ${ }^{+}$-dependent CNS demyelination following ocular infection of mice with a recombinant HSV-1 expressing murine IL-2. Exp Neurol 2005, 193:1-18.

39. Zandian M, Belisle R, Mott KR, Nusinowitz S, Hofman FM, Ghiasi H: Optic neuritis in different strains of mice by a recombinant HSV-1 expressing murine interleukin-2. Investig Ophthalmol Vis Sci 2009, 50:3275-3282.

40. Mott KR, Gate D, Zandian M, Allen SJ, Rajasagi NK, van Rooijen N, Chen S, Arditi M, Rouse BT, Flavell RA, Town T, Ghiasi H: Macrophage IL-12p70 signaling prevents HSV-1induced CNS autoimmunity triggered by autoaggressive CD4 ${ }^{+}$Tregs. Investig Ophthalmol Vis Sci 2011, 52:2321-2333.

41. Kastrukoff L, Lau A, Osborne D, Kim SU: Herpes simplex virus type 1 (HSV 1): A murine model of virus induced central nervous system demyelination. In Myelination and Demyelination. Implications for Multiple Sclerosis.. 1 edition. Edited by: SU Kim. New York and London: Plenum Press; 1989:153-171.

42. Kastrukoff LF, Lau AS, Leung GY, Thomas EE: Contrasting effects of immunosuppression on herpes simplex virus type 1 (HSV 1) induced central nervous system (CNS) demyelination in mice. J Neurol Sci 1993, 117:148-158.

43. Drescher KM, Sosnowska D: Being a mouse in a man's world: what TMEV has taught us about human disease. Front Biosci 2008, 13:3775-3788.

44. Fazakerley JK: Semliki Forest virus infection of laboratory mice: a model to study the pathogenesis of viral encephalitis. Arch Virol 2004, 18:179-190.

45. Schaumberg CS, Held KS, Lane TE: Mouse hepatitis virus infection of the CNS: a model for defense, disease, and repair. Front Biosci 2008, 13:4393-4406.

46. Vandevelde $M$, Zurbriggen A: Demyelination in canine distemper virus infection: a review. Acta Neuropathol 2005, 109:56-68.

47. Margolis TP, LaVail JH, Setzer PY, Dawson CR: Selective spread of Herpes simplex virus in the central nervous system after ocular inoculation. $J$ Virol 1989, 63:4756-4761.

48. LaVail JH, Topp KS, Giblin PA: Factors that contribute to the transneuronal spread of Herpes simplex virus. J Neurosci Res 1997, 49:485-496.

49. Sun N, Cassell MD, Perlman S: Anterograde, transneuronal transport of Herpes simplex virus type 1 strain $\mathrm{H} 129$ in the murine visual system. J Virol 1996, 70:5405-5413.

50. Blessing WW, Ding Z-Q, Li Y-W, Gieroba ZJ, Wilson AJ, Hallsworth PG, Wesselingh SL: Transneuronal labeling of CNS neurons with herpes simplex virus. Prog Neurobiol 1994, 44:37-53.

51. Ugolini G, Kuypers HGJM, Strich PL: Transneuronal transfer of herpes virus from peripheral neurons to cortex and brainstem. Science 1989, 243:89-91.

52. Webb SJ, Eglin RP, Reading M, Esiri MM: Experimental murine herpes simplex encephalitis: immunohistochemical detection of virus antigens. Neuropathol Appl Neurobiol 1989, 15:165-174.

53. Bak IJ, Markham CH, Cook ML, Stevens JG: Ultrastructural and immunoperoxidase study of striatonigral neurons by means of retrograde axonal transport of herpes simplex virus. Brain Res 1978, 143:361-368.

54. Cook ML, Stevens JG: Pathogenesis of herpetic neuritis and ganglionitis in mice: evidence for intra-axonal transport of infection. Inf Immun 1973, 7:272-288

55. Kristensson K: Morphological studies of the neural spread of herpes simplex virus to the central nervous system. Acta Neuropath 1970, 16:54-63.

56. Openshaw H, Ellis WG: Herpes simplex virus infection of motor neurons: Hypoglossal model. Inf Immun 1973, 42:409-413.

57. Vahlne A, Nystrom B, Sandberg M, Hamberger A, Lycke E: Attachment of Herpes simplex virus to neurons and glial cells. J Gen Virol 1978, 40:359-371.

58. Vahlne A, Svennerholm B, Sandberg M, Hamberger A, Lycke E: Differences in attachment between Herpes simplex type 1 and type 2 viruses to neurons and glial cells. Inf Immun 1980, 28:675-680.

59. Enquist LW, Husak PJ, Banfield BW, Smith GA: Infection and spread of alphaherpesvirues in the nervous system. Adv Virus Res 1999, 51:237-347.

60. Card JP, Rinaman L, Lynn RB, Lee BH, Meade RP, Miselis RR, Enquist LW: Pseudorabies virus infection of the rat central nervous system: 
Ultrastructural characterization of viral replication, transport, and pathogenesis. J Neurosci 1993, 13:2515-2539.

61. Rinaman L, Card JP, Enquist LW: Spatiotemporal responses of astrocytes, ramified microglia, and brain macrophages to central neuronal infection with pseudorabies virus. J Neurosci 1993, 13:685-702.

62. Blessing WW, Li Y-W, Wesselingh SL: Transneuronal transport of Herpes simplex virus from the cervical vagus to brain neurons with axonal inputs to central vagal sensory nuclei in the rat. Neuroscience 1991, 42:261-274.

63. Norgren $R$, Lehman M: Retrograde transneuronal transport of herpes simplex virus in the retina after injection in the superior colliculis, hypothalamus, and optic chiasm. Brain Res 1989, 479:374-378.

64. Thomas EE, Lau AS, Kim SU, Osborne D, Kastrukoff LF: Variation in resistance to herpes simplex virus type 1 of oligodendrocytes derived from inbred strains of mice. J Gen Virol 1991, 72:2051-2057.

65. Thomas EE, Lau AS, Morrison B, Kim SU, Kastrukoff LF: Differences in resistance to herpes simplex virus type 1 (HSV-1) among oligodendroglia derived from different strains of mice are determined after viral adsorption but prior to the expression of immediate early (IE) genes. J Neurovirol 1997, 3:197-205.

doi:10.1186/2042-4280-3-4

Cite this article as: Kastrukoff et al:: The effect of mouse strain on herpes simplex virus type 1 (HSV-1) infection of the central nervous system (CNS). Herpesviridae 2012 3:4.

\section{Submit your next manuscript to BioMed Central and take full advantage of:}

- Convenient online submission

- Thorough peer review

- No space constraints or color figure charges

- Immediate publication on acceptance

- Inclusion in PubMed, CAS, Scopus and Google Scholar

- Research which is freely available for redistribution

Submit your manuscript at www.biomedcentral.com/submit 